\title{
Using Of Sun Power Plant To Light Out The Residential Environment Of Lau Damak Village
}

\author{
Budi Utomo ${ }^{1 *}$, Afifuddin Dalimunthe ${ }^{1}$,Muhammad Husni ${ }^{2}$ \\ ${ }^{1}$ Faculty of Forestry, Universitas Sumatera Utara, Kampus USU Padang Bulan, Medan \\ 20155, North Sumatra, Indonesia \\ ${ }^{2}$ Faculty of Law, Universitas Sumatera Utara, Kampus USU Padang Bulan, Medan 20155, \\ North Sumatra, Indonesia \\ *email: budiutomo@usu.ac.id
}

\begin{abstract}
Until now, it seems that electricity is still a challenge in Indonesia, there are still many who have not enjoyed electricity for those who live in suburban or coastal areas, and some are located not far from cities. The target area is relatively close to the center of the capital, but has escaped the attention of the government because the location is quite remote with a minimal population, so it is considered uneconomical to provide electricity to this area. This hamlet is also inhabited by less than 18 families, so that only those with an interest are left in and out of this hamlet. The remote location from one house to another makes the construction of the electricity network no longer efficient for State Electricity Company. Therefore, people must be willing to live without electricity. Lighting as a basic need must be met from an oil lamp (sentir). Some residents who have a few advantages will buy individual generators. This generator only operates from $06.30 \mathrm{pm}$ to $09.00 \mathrm{pm}$. After entering the sleep time, the generator is immediately turned off, the lighting is continued using an oil lamp. The emergence of the USU Community Services Implementing Team to this partner area provided new hope for the community. The community enthusiastically complained about this condition and hoped that the USU Community Services Implementation Team could help with these residents' problems. The results of monitoring by the Community Services Implementing Team at several residents 'houses proved the residents' complaints. Electric lighting as a basic need for residents is believed to be able to be completed using existing knowledge at the university in the form of lighting using solar power. Science and Technology The USU Community Services Team through the joining program has now produced economical science and technology products and realizes the expectations of the people in this region. Now people can enjoy light for 24 hours using electricity from solar energy. The community would like to thank the team and university for the scientific products that were donated to this village.
\end{abstract}

Keywords: remote, no electricity, lighting, solar electricity.

\section{INTRODUCTION}

\subsection{Situation Analysis}

Lau Damak Village is one of the villages located in Bahorok District, Langkat Regency, North Sumatra, whose territory is directly adjacent to the Gunung Leuser National Park and is designated as a national park buffer zone. This village is directly adjacent to the mountainous forest area which contains limestone mountains. Lau Damak Village has 7 hamlets, including Hamlet 1 (Lau Damak), Hamlet 2 (Namo Cengkeh), Hamlet 3 (Selayang), Hamlet 4 (Sukamulia), Hamlet 5 (Tanjung Naman), Hamlet 6 (Tusem Pinter), and Hamlet 7 (Ujung Gorap) with a total of 560 family heads. In this village, there are still several places that do not enjoy the benefits of direct electricity, one of which is the Tusem Pinter hamlet. Tusem Pinter Hamlet has a part of the area called Tanjung Bringin. Tanjung Bringin is directly adjacent to the limestone mountain forest area, and is located in an area that is quite remote so that this area is far from the electricity source of the State Electricity Company installation. The majority of the population of Tanjung Bringin works as farmers and small businesses. Meanwhile, the residents of Tanjung Bringin have submitted requests for electricity to the parties concerned, but the installation of electrical installations has not been realized due to uneconomic reasons. Electricity has entered Indonesia since the end of the 19th century. The house that used to be lit only by oil lamps after sunset now looks brighter. However, in reality, not all Indonesians have enjoyed electricity. Of the 250 million population of Indonesia, only 190 million people benefit from electricity managed by State Electricity 
Company. The conditions and challenges for electricity in Indonesia today, there are still many who do not enjoy electricity, generally they live in suburban or coastal areas, but some are located not far from cities. Administratively, Lau Damak village is one of the villages that is quite close to the center of the provincial capital (Medan City), which is $80 \mathrm{~km}$, or only $55 \mathrm{~km}$ from the city of Binjai. However, in reality, until now, one of the hamlets in this area has not been touched by electricity.

The target partners in this community partnership program are community groups whose members are farmers / planters who live in the Tusem Pinter hamlet. Members of farmer groups in this area generally work as farmers or planters. In general, people plant oil palm with an average ownership of 0.5-1 ha / family. In general, members of this community group tend to build houses close to their place of business. Therefore, it is not surprising that the residents' houses are far from one another. The distribution of houses that are far apart causes the opportunity for the construction of the State Electricity Company electricity network to be no longer efficient. Therefore, until now the houses of these residents have not been served by electricity.

Economic limitations have caused residents as members of this farmer group to be willing to live without electricity. Everyday lighting at night is obtained from oil lamps. The financial limitations of residents in buying fuel have caused residents who have private generators to only be able to turn on electricity until 21.00 WIB, which is followed by lighting oil lamps (sentir) until the morning.

The absence of public lighting inevitably also creates security vulnerabilities. Therefore residents are not free to travel for this reason. Residents complained about the need for public street lighting at certain points to reduce potential criminal acts that may arise due to dark access roads to and from their respective homes at night. Therefore, until now residents have anticipated it by not going out / coming home too late to reduce the risk of robbery on the street.

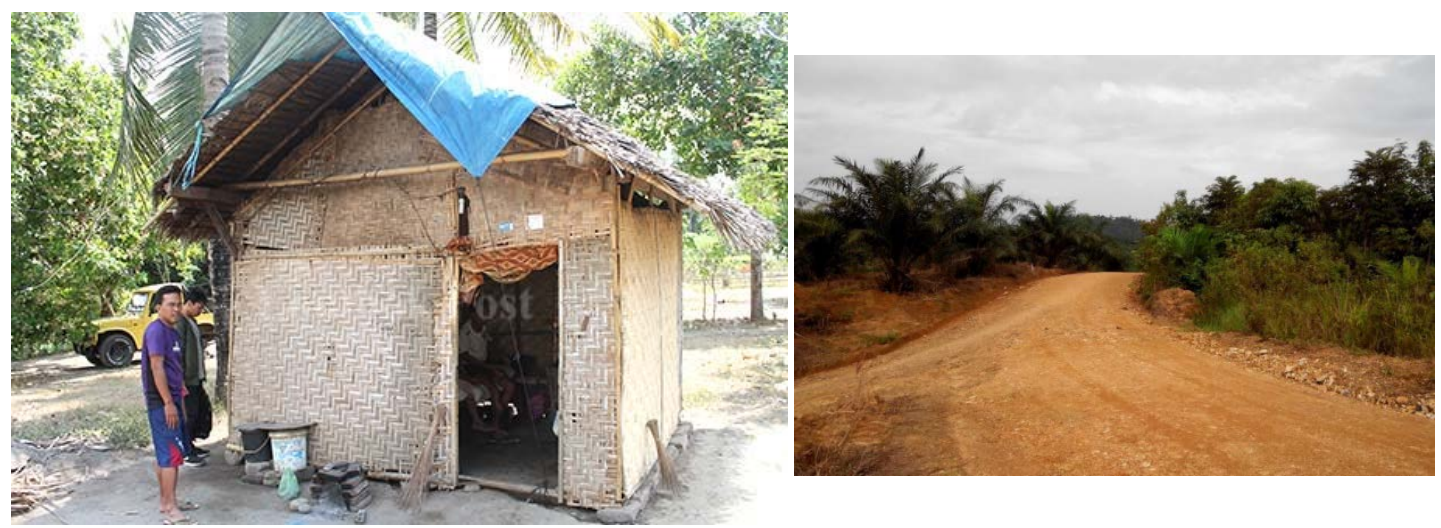

Figure 1.1. House conditions of members of farmer group members who live in areas close to their garden / agricultural areas without electricity facilities (left); The road to the settlement of members of the two farmer groups without lighting is prone to threats of crime at night (right)

According to residents who are partners in the Community Services activity plan (the head of the farmer groups), the residents have complained about this condition to the local village government, but until now this community's wishes have not been served considering the limited budget available. The absence of knowledge has resulted in society continuing to live without electric lighting.

\subsection{Partner Problems}

Partners in the Community Services are planned to be community groups living in the GLNP forest boundary, namely Tusem Pinter Hamlet, Lau Damak Village, Langkat Regency. When the USU Community Services Team visited the location it was received by the community and the Village Secretary who live near this hamlet. In deliberations with the community, the Team tried to explore the main problems faced by the community. Based on the results of the deliberations, it was found that Tusem Pinter Hamlet was still facing electricity problems. The residents of this hamlet who are members of partner farmer groups who live spread across their garden business areas have not been 
able to enjoy State Electricity Company electricity services. Electricity needs are met from oil lamps (sentir). The distance between the plantation residents means that State Electricity Company is unable to provide electricity to these residents because it is no longer efficient for State Electricity Company. Even so, quite a lot of people live without this electricity facility. No less than 18 houses in this area still use oil lamps. The absence of public lighting inevitably also creates security vulnerabilities. Therefore, until now residents have anticipated it by not going out / coming home too late to reduce the risk of robbery on the street. Electricity as a basic need for the community is now a priority issue for partners that need to be resolved. The community has often complained about this electricity problem to the village and sub-district governments. Budget limitations and low of district incomes are again reasons for the local government so that the construction of this network has not been carried out. Higher education science and technology support is needed to accelerate the improvement of community welfare in this region.

The appearance of the USU Community Services Implementation Team to Lau Damak Village gave new hope to the community. The community enthusiastically complained about this condition and hoped that the USU Community Services Implementation Team could help overcome these residents' problems. The results of monitoring by the Community Services Implementing Team at several residents 'houses proved the residents' complaints. The Community Services Team tries to provide solutions to solve these community problems through the proposed community partnership program. The availability of funds sourced from USU's Non-PNBP funds in 2020 must be able to help overcome community problems through university science and technology.

\section{METHODS}

The Community Services for USU Fund from non-PNBP for the 2020 budget is implemented in the Tusem Pinter Hamlet, Lau Damak Village, Bahorok District, Langkat Regency. The activity lasts for 6 months from the start of the activity until the submission of the activity report. Learning activities are carried out by providing theory which is carried out in such a way that it is easily understood and understood by the community. The use of equipment in the form of an LCD projector is a vital means to be used, so that it will further increase public interest in the topics presented. As for learning activities, it will be carried out through theory and applied activities in the field that will be carried out by the community, students and lecturers at the University of North Sumatra who have competence with the respective fields of activity to be carried out. To support the realization of the success of the Community Services offered, the problem solving procedure is carried out in the following order:

1. Identification of the problem

The process of identifying problems includes activities to explore problems from the local community followed by a survey of the location of the problem. Problem identification uses the focused discussion group (FGD) method that involves the target village community as well as community leaders and village heads and village officials (Badollahi, 2013). From the results of the FGD, it was decided that priority issues should be resolved immediately in the target villages. Based on the results of the FGD, it was found that the majority of the community complained about the lack of means of information, which is a vital means of socializing society. Immediately after exploring a number of problems faced by the community, the Community Services Team then conducted sampling visits to the houses of residents in the target villages. The Community Services Team also conducted consultations with home owners to gather information about problems faced by residents and the efforts that have been made.

2. Selection of alternative problem solving and analysis methods

After identifying the problem, the USU Community Services Team decided on the partner's priority problems and then took the problem to the university to discuss problem-solving techniques with consideration of limited costs, time and the effectiveness of the methods used. The funds obtained must be able to produce science and technology products that can be directly used to solve problems. The problem solving activity was carried out at the original university, namely at USU. This is because USU has sufficient and capable resources. In addition, USU also has workshops and units that have the ability to create the required science and technology products.

3. Analysis of the availability of raw materials for forming science and technology products 
The Community Services Team conducted a market analysis related to the availability of raw materials for producing systems for science and technology equipment, such as solar panels, DC lamps, cables of various sizes, inverters, controllers, bolts, nuts, iron pipes of various sizes, anti-thef solar street lamps, auto flash, etc. In this case, it can be ensured that all the raw materials are sufficiently available in the market and can be used for the completion of the manufacture of lighting lamps.

4. Analysis of the ability of the workshop / workshop to create an independent lighting system

The Community Services Team conducted a workshop analysis on the ability and availability of equipment needed for the process of making an independent lighting system using a solar power generating system. If the facilities in the laboratory owned by the Faculty of Engineering are not sufficient, the Team will use other workshops / workshops outside USU that are capable of carrying out the work of making this equipment.

5. Design tools

The design of the solar power plant and public street lighting tools is carried out by describing the tools that will be made in the laboratory. These pictures will then be followed up by making the solar power plant and public street lighting working system after all the materials and equipment are available.

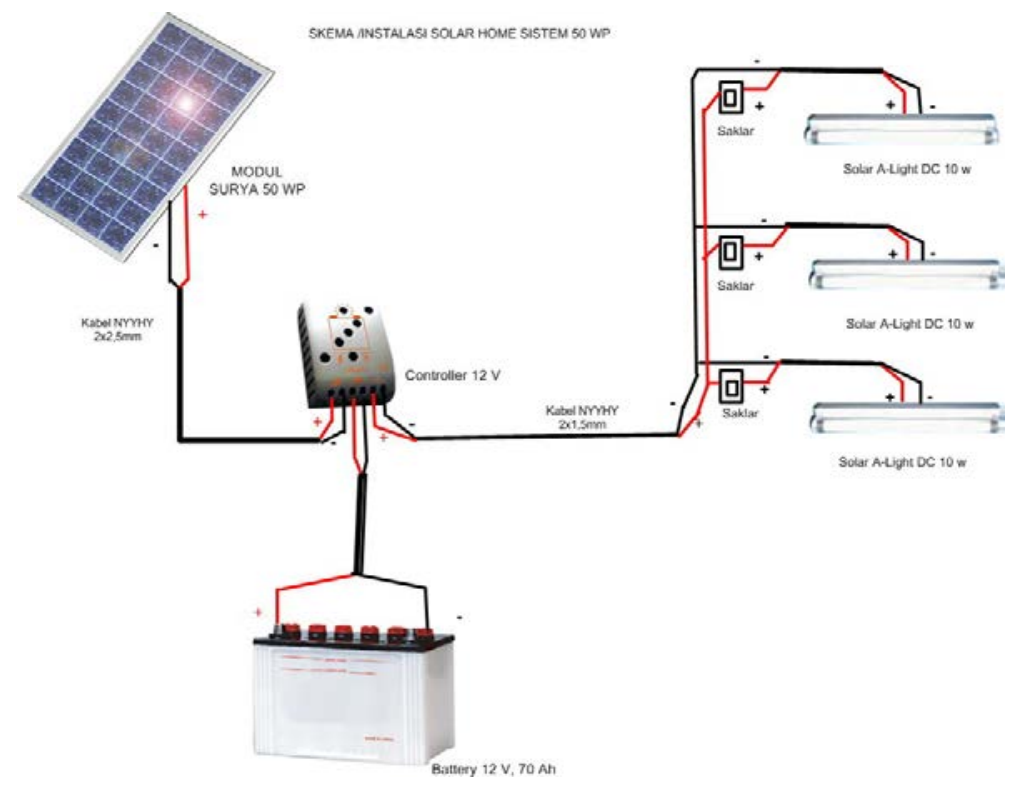

Figure 3.1. The independent solar power plant installation system for residents' housing needs (left), as well as solar street lighting (right) which will be made by the Community Services Implementation Team (Ramadhan, et al., 2017)

\section{Equipment installation}

The installation of solar power plant and public street lighting equipment is carried out according to the design that has been made. In principle, electricity harvested from solar energy will be flowed using a brass cable to the 20 A charger controller which is then forwarded to the storage battery in the public street lighting light kit. In the area on this hamlet road, which is considered vulnerable at night, it will be fitted with public street lighting using solar electricity.

7. Supervision and maintenance

After the installation of the public road PV mini-grid equipment system is installed, the next action is supervision and maintenance activities. In this case, training is conducted for farmer group partners to understand the solar power plant system developed in their area. This is intended to ensure the sustainability of the information program from the science and technology tools that are donated. Activities undertaken include:

a. Learning about the working system of the solar power plant equipment system and its maintenance techniques to the supplier of spare parts if the system is damaged 
b. Each farmer group partner forms a structure that is responsible for the operational continuity of the solar power plant built and its installation.

c. The solar power plant group will be quoted a number of funds that will be used for maintenance of the equipment system for the needs of replacing public street lighting spare parts.

Community Services activities that are carried out, of course, must involve partners for the success of the program of activities being carried out. Activity partners in this case are community groups in the target village. In this community partnership implementation plan the partners have expressed their willingness to participate. The participation is in the form of:

a. Target community groups participate in training activities on the use of science and technology products in the implementation of community services activities.

b. Given the limited funds that might be obtained from the USU Community Services Team, community groups as part of the target community took the initiative to work together to help install household lighting systems and PJU and promised to continue program activities after the USU Community Services Team had finished implementing community Services activities in the target villages in the form of establishing maintenance group. Partners will also form a solar power plant and public street lighting management structure that will organize the collection of funds for replacement parts and equipment maintenance costs.

After the community services activities are completed, an evaluation is carried out to determine the extent to which community services activities have an impact on the community in the form of: public interest in participating in activities, community motivation to study the science and technology program delivered, partner satisfaction with the Community Services products implemented, and the level of success. Community services implemented. To strive for the sustainability of the program after the community services activities have been completed, the community services implementing team conducts training on simple solar power plant installation procedures for the community. In addition, the team also explained the function of each tool and conveyed the sources of spare parts that could be obtained for the community. This is an important thing considering that solar power plant is considered a new and complicated technology for the community. With this teaching, it is hoped that people who have not received lighting facilities due to limited costs from the USU Community Services Team this time will be able to make their own installations so that the problem of electricity needs for residents' lighting can be resolved in this area.

\section{RESULT AND DISCUSSION}

One of the hamlets in Lau Damak Village, Tusem Pinter Hamlet, which is better known as Tanjung Beringin Hamlet, has long been untouched by electricity. This hamlet has been around since the 1980s. However, considering its location which is far from other hamlets in Lau Damak Village, this hamlet has become an isolated hamlet. It is about 4-5 km from other hamlets and the small number of houses in this hamlet has made State Electricity Company reluctant to supply electricity to this area due to uneconomic reasons. So until now this hamlet has never enjoyed electricity. At night the houses are completely dark and only accompanied by oil lamps which are often called teplok lamps. The habit that lasts for a long time has resulted in people getting used to this condition. It's just that fortunately because of its isolated location and far from other settlements, this hamlet is classified as safe because not many people enter and leave this hamlet at night. The entry of the Community Services Implementation Team from USU provided fresh air for residents to express their hearts. Together with other Community Services Implementation Teams, the Team tries to provide solutions for community members. Armed with the very limited community service funds obtained from USU's Non-PNBP funds, the USU Community Services Implementation Team shared tasks. Another team carried out the construction of solar power plant for residents' houses, while the Community Services Implementing Team carried out the installation of solar power plant for public street lighting. This is intended to provide a sense of security for residents, especially with the location of the hamlet which borders the Gunung Leuser National Park (GLNP) which allows wild animals to enter and exit the hamlet. 
Recently, it was reported that the residents' cattle were being eaten by tigers who came from GLNP to enter an area that had received light.

Through regular annual community service activities, the USU Community Services Team built a solar power plant for residents of Tanjung Beringin Hamlet, Lau Damak Village, Bohorok District, Langkat Regency. This very isolated area borders the GLNP with poor access only 4 x 4 jeep vehicles can pass. This difficulty is exacerbated by the distance this area is from other hamlets, making access to this hamlet very difficult. No less than 18 families live in this hamlet. According to local resident Erdison Ginting, there were more people living in this hamlet, however, due to the absence of electricity, the residents moved to other hamlets that had received electricity facilities. The residents said they had lived in this hamlet for a long time because they wanted to live not far from the garden where they worked. Poor access makes it difficult to get in and out of the area if you have to live outside of this hamlet.

Residents have long complained about this through the Village Head of Lau Damak, but until now there has been no sign that this area will be touched by State Electricity Company. The entry of the Community Service Implementation Team, which promised to find a solution some time ago, provided fresh air for residents.

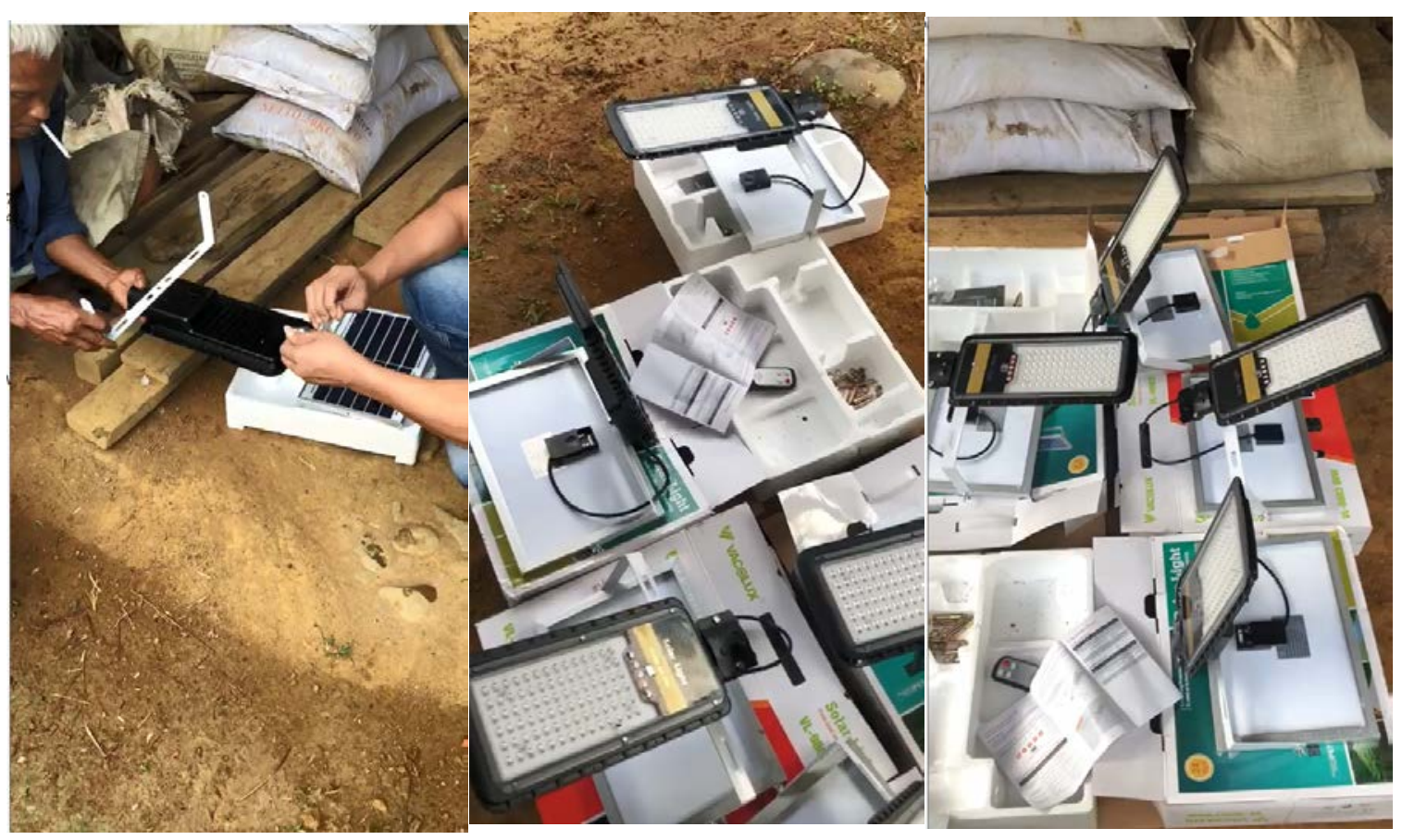

Figure 3.1 The process of transporting PJU poles to the village using a 4 x 4 vehicle due to the rugged terrain (left); The process of installing PJU light poles with residents (right)

Given the long distance due to the isolated location, the Team implemented a strategy to conduct training for the residents of Tanjung Beringin Hamlet so that workers could be obtained from the hamlet itself. Together with the residents, the USU Community Services Implementation Team built a PJU network for this hamlet. The community was very enthusiastic about following the guidance and directions carried out by the Community Services Implementation Team. The team is experienced enough to carry out this activity considering that it has several times installed public street lighting networks in other isolated areas.

In addition to installing electric poles, residents are also very enthusiastic about learning about the public street lighting work system built by the USU Community Services Implementation Team. This is very understandable considering this is also a new thing for society. The electronic equipment 
installed using a lot of chips and electronic devices inevitably becomes a spectacle for all citizens of society. To illuminate the neighborhood, The Community Services Implementation Team installed 8 units of public street lighting light poles. Each pole is fitted with an automatic solar cell public street lighting lamp with 80 watts of power that will illuminate the residents' environment from late afternoon until early morning. In order to make it easier for residents, the lighting system uses auto flash which allows the lights to turn on if there is no sunlight, and will turn off automatically in the morning. In the morning the system will automatically charge the battery for charging which will turn on the lights at night. And so on this system works.

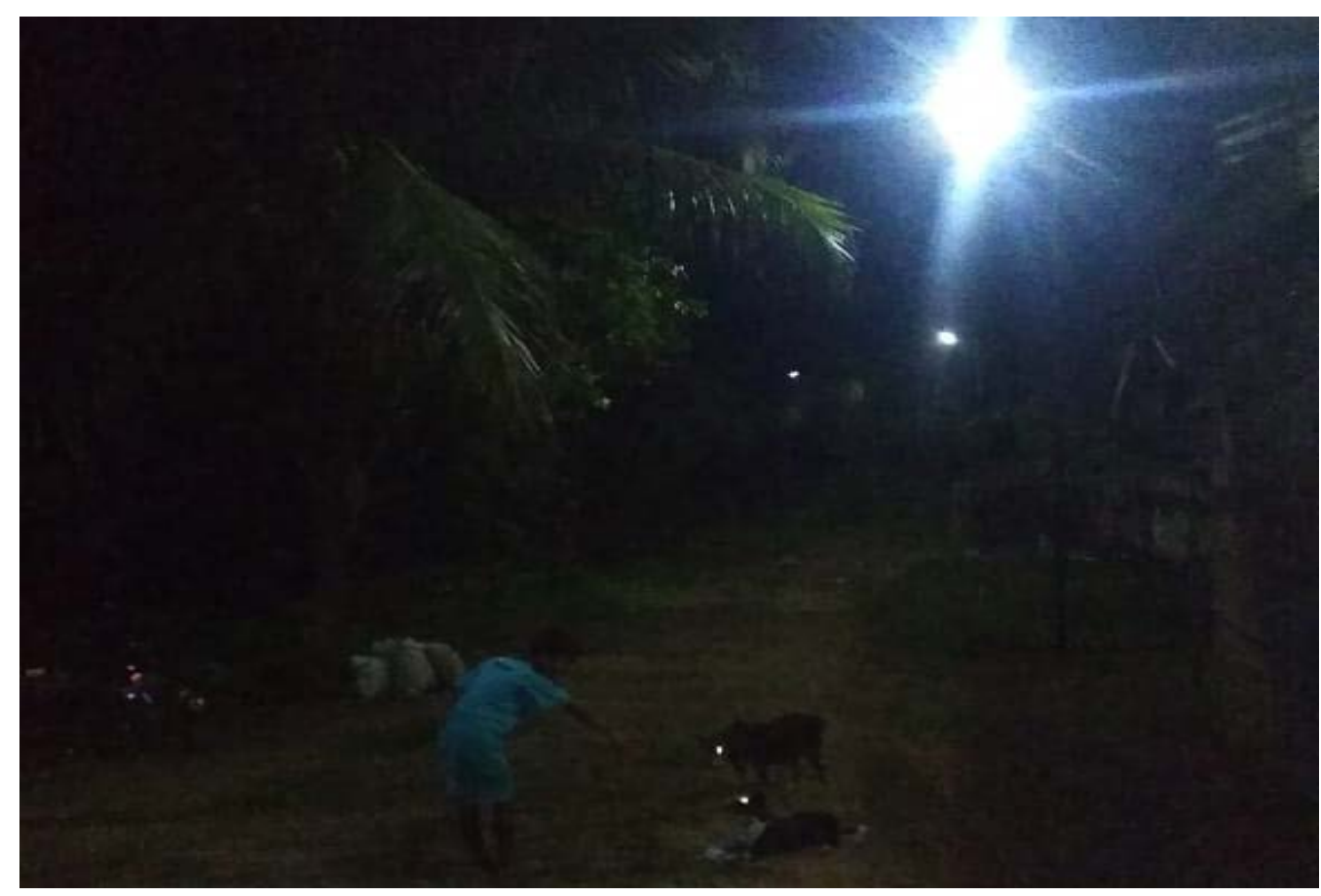

Figure 3.2 PJU lighting equipment assembled by the USU Community Services Implementation Team

To turn on the lights at night, a remote control is used for the first time which can be used to adjust the life of the lights to suit the wishes of the residents, whether it stays on all night, or uses a motion sensor, which means that if there is movement under the lights, the lights will light up brightly and will dim if There is no movement. This is intended to save the power contained in the lithium battery embedded in this public street lighting device.

Now residents can have fun at night because they can enjoy the beauty of the night with public street lighting lights in addition to the solar power plant lights built by other USU Community Services Implementation Team groups. Residents say that this hamlet was very quiet at night, but with this lighting the children often played in the yard because of the public street lighting in this area. The residents are very grateful to the USU Community Services Implementation Team for their donations. Likewise, the village head of Lau Damak, Mr. Ngemat Ginting directly expressed his deep gratitude for the attention of the USU Community Services Implementing Team to its residents.

Figure 5. Public street lighting has functioned at night, children can play outside because of the lighting

\section{CONCLUSION}


Based on the results of the activities during the period of 6 months of community partnership activities in the Tusem Pinter Tanjung Beringin Hamlet, Lau Damak Village, Bohorok District, Langkat Regency, the following conclusions were obtained:

1. The activity of making lighting for the public street lighting environment for residents of the Tanjung Beringin Tusem Pinter Hamlet, Lau Damak Village, Bohorok District, Langkat Regency has been carried out with an implementation rate of $100 \%$

2. The community stated that they were very satisfied and grateful to the USU Partnership Team for carrying out community Services activities in this area.

\section{Suggestion}

For the sustainability of the program, the community should make regular monthly deductions for funds for maintenance and purchase of damaged equipment. It is better if funds are collected independently so that people can enjoy this public street lighting because the age of use of PJUs that are donated to community members is around $2-3$ years.

\section{ACKNOWLEDGMENTS}

Through this article, the author would like to express his gratitude to the University of North Sumatra for the 2020 Non-PNBP Community Service Fund Grant.

\section{REFERENCES}

Akhmad, K. 2011. Solar Power Generation and Its Application for Remote Areas, Journal of Engineering Dynamics 1 (1): 28- 33

Arfianto AEW and Balahmar ARU. 2014. Community Empowerment in Village Economic Development. JKMP 2: 1 1-93.

Badollahi A. 2013. Towards Village Development 2015-2019. National Policy Direction and Development Strategy for Rural Areas. http://media.kompasiana.com/ Buku / 2014/10/31 / Towards-Development-Village-2015-2019-684013.html

[BPS] Central Bureau of Statistics. 2015. Langkat Regency in Figures 2018. Annual Publication Series of BPS Langkat Regency, North Sumatra Province.

[USU's LPPM] Community service institution. 2016. Program activities. http://usu.ac.id/id/ (accessed April 05, 2016).

Rahayuningtyas, A., Kuala, SI, and Apriyanto, F. 2014. Study on Planning of Simple House Scale Solar Power System (PLTS) in Rural Areas as an Alternative Power Plant to Support Environmentally Friendly and Renewable Energy Programs, Proceedings of the 2014 SnaPP Science, Technology, and Health pp. 223-230.

Ramadhan A.I., Diniardi E, Mukti S. H. 2016. Analysis of Solar Power System Design with a Capacity of 50 WP. Engineering 37 (2), 2016, 59-63.

Salman R. 2013. Planning Analysis of the Use of Solar Power Generation Systems (PLTS) for Housing (Solar Home System). Smartek Journal, 4 (3) 46-51.

Subandi and Hani S. 2015. Solar Energy Power Generation as Driving Water Pump Using Solar Cell, Technoscientia Journal of Technology 7 (2): 157-163

[USU]. University of Northern Sumatra. 2016. Facilities and resources. http://ppmusu.ac.id/id/ (accessed April 05, 2016). 